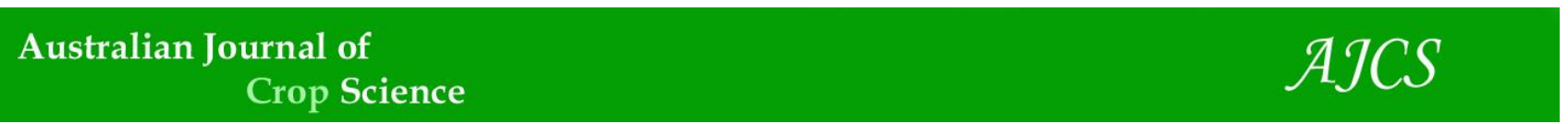

AJCS 14(05):788-794 (2020)

ISSN:1835-2707

\title{
Agronomic characteristics of soybean under the production and decomposition of sunflower and Paiaguas palisadegrass biomass in different integrated production systems
}

\author{
Itamar Pereira de Oliveira', Kátia Aparecida de Pinho Costa ${ }^{1 *}$, Renato Lara de Assis ${ }^{2}$, Eduardo da Costa \\ Severiano ${ }^{1}$, Mariana Borges de Castro Dias ${ }^{1}$, Charles Barbosa dos Santos ${ }^{1}$ \\ ${ }^{1}$ Goiano Federal Institute, Graduate Program in Agricultural Sciences, Rio Verde, Goiás, Brazil \\ ${ }^{2}$ Goiano Federal Institute, Iporá, Goiás, Brazil
}

*Corresponding author: katia.costa@ifgoiano.edu.br

Abstract

With the adoption of integrated production systems, relative gains in soybean yield have been achieved due to the permanence of vegetal residues on the soil surface. These residues favour the soil microbiota responsible for the decomposition of organic matter and nutrient cycling, which makes integrated agrosystems sustainable. The objective of this study was to evaluate the agronomic characteristics of soybeans under the production and decomposition of sunflower and Paiaguas palisadegrass biomass in different integrated production systems. The experiment was conducted off season in a dystroferric Red Latosol soil in a randomized block experimental design with four replicates. The treatments consisted of the following forage systems: monocropped sunflowers; monocropped Paiaguas palisadegrass; row sunflowers $x$ Paiaguas palisadegrass; inter-row sunflowers $x$ Paiaguas palisadegrass; and oversown sunflowers $x$ Paiaguas palisadegrass. The results showed that the monocropped sunflower and Paiaguas palisadegrass presented the highest biomass production throughout the soybean development cycle, with the slowest decomposition, representing a strategy to increase soil cover efficiency mainly in the period prior to summer planting. The soybean cultivated in the biomass of the monocropped Paiaguas palisadegrass and the Paiaguas palisadegrass intercropped in rows and in inter-rows presented better yields and was positively influenced by the production parameters compared with soybean cultivated otherwise. Therefore, sunflower intercropped with Paiaguas palisadegrass during the off season in the Central-West Region of Brazil was shown to be a promising and sustainable cultivation technique for the production of biomass for no-tillage systems.

Keywords: Brachiaria brizantha. Crop-livestock integration. Helianthus annuus L.

Introduction

The intensive use of Cerrado-region soils for agricultural production, together with inadequate soil management, has caused soil degradation and a consequent decrease in the productivity of crops and the agricultural sector. In view of the growing global demand for food, fibre, wood and biofuels and the consequent need to expand the agricultural frontier, systems of crop-livestock integration are highlighted as an alternative for sustainable production insofar as they provide optimal use of soil with environmental gains and increased productivity (Silva et al., 2010).

As an alternative for use in crop-livestock integration systems, annual crops such as sunflower (Souza et al., 2015; Santos et al., 2016; Cruvinel et al., 2017; Miguel et al., 2018) have appeared. Sunflower is considered one of the oilseeds with the highest growth rates both in cultivation and in production and is currently classified as the second-largest source of raw material for the edible oil industry; the vegetable oil produced from sunflower is of excellent nutritional quality. As a result, sunflower cultivation is rapidly growing, mainly in the Central-West Region, and large companies are strategically installed to promote technological advancement (Santos et al., 2016).

Under the tropical and subtropical conditions of Brazil, integrated systems of annual crops and perennial grasses of the genus Brachiaria are excellent alternatives for establishing Brachiaria as ground cover (Almeida et al. 2017; Oliveira et al., 2019). Among Brachiaria species, we highlight Paiaguas palisadegrass, which is another excellent option for the diversification of pastures in soils of medium fertility in the Central-West Region of Brazil and has contributed to the growth of integrated systems due to its advantages of good regrowth in the dry season, ease of desiccation and excellent nutrient cycling (Costa et al., 2016; Costa et al., 2017; Guarnieri et al., 2019).

In addition, Machado et al. (2017) reported that Paiaguas palisadegrass stands out for having characteristics favourable to intercropping, such as the presence of thin stalks, which facilitate lodging. Plants with these characteristics may have a low competition capacity for solar radiation, which for soybean reduces the risk of damage to grain yield. 
However, the correct choice of plant species for use in an integrated system for the production of biomass at the soil surface is extremely important for the success of the system since the climatic factors characteristic of each region and the soil type influence the growth of plant species (Costa et al., 2015). In the Central-West Region of Brazil, the climate is characterized by a dry winter, high temperatures throughout the year and a prolonged dry season; these characteristics hinder the production of biomass in cultivated areas, as these factors are major obstacles to the maintenance of the system.

Thus, efficient soil cover with biomass is one of the factors that most limits the sustainability of the system in the Central-West Region, mainly due to the accelerated decomposition of the residues. The need to produce plant residues with slower decomposition rates is therefore reinforced, and such production involves keeping the residue on the soil for a longer period of time, especially in the off season (Costa et al., 2015).

The objective of this study was to evaluate the agronomic characteristics of soybean under the production and decomposition of sunflower and Paiaguas palisadegrass biomass in different integrated production systems.

The hypothesis of this study is that biomass production varies under different production systems. The intensification of systems including Paiaguas palisadegrass in monoculture and intercropped with sunflower positively affects soybean crop cultivated in succession.

\section{Results and Discussion}

Decomposition of the remaining biomass and the $\mathrm{C} / \mathrm{N}$ ratio There was an influence $(p<0.05)$ of forage systems on the remaining biomass and the $\mathrm{C} / \mathrm{N}$ ratio. (Figures 2 and 3 ). The highest yields, measured as the biomass remaining at 30 days, were observed under monocropped sunflower, followed by monocropped Paiaguas palisadegrass. This result may be due to the lack of competition between plants when compared to the consortium. However, it is worth noting that although sunflower presented higher biomass production, it presented lower soil cover.

In the monocropped and intercropped systems of Paiaguas palisadegrass, the biomass was more distributed in the soil due to its caespitose growth habit and its capacity to issue new tillers, even in periods of low precipitation (Figure 1), thus forming well-distributed soil cover for subsequent soybean cultivation (Figure 2).

According to Costa et al. (2015), the appropriate choice of plant species for the production of biomass on the soil surface is important for the success of a no-tillage system, and the climatic factors characteristic of each region and soil type must be considered. Biomass production in no-tillage systems provides diversity, minimizes crop loss risks, and enhances the options for succession adoption and crop rotation (Horvathy et al., 2012).

Previous sunflower consortium systems with Paiaguas palisadegrass in the rows and inter-rows provided biomass that remained at 30, 60, 90 and 120 days after cutting (Figure 2). Therefore, it is important to consider that when forage is intercropped, there is competition between species, especially when they are sown simultaneously. In the present study, Paiaguas palisadegrass was sown at a depth of $6 \mathrm{~cm}$, and in the planting of the intercropped system, the Paiaguas palisadegrass was sown $40 \mathrm{~cm}$ from the sunflower line, which created less competition between plants.

In all evaluation periods, sunflower oversown with Paiaguas palisadegrass obtained the lowest production of biomass (Figure 2). This result is due to the low development of Paiaguas palisadegrass when it was sown 15 days after sunflower emergence because the large leaf area of the growing sunflower plants shaded the Paiaguas palisadegrass. Therefore, this system is not the best system for sowing because it drastically affects forage production.

Average biomass productivity is an important parameter because it reflects the amount of plant biomass that can return to the soil after grain harvest and benefits subsequent crops through high moisture retention and good temporal availability of nutrients in the soil due to the rapid decomposition of the leaves and roots, unlike that of the stem (Lobo et al., 2012).

The half-life of the biomass was higher in monocropped sunflower and lower in monocropped Paiaguas palisadegrass. This difference is due to the higher $\mathrm{C} / \mathrm{N}$ ratio of sunflower (Figure 2) and the higher number of leaves and lower amount of lignified material (which decomposes easily) of Paiaguas palisadegrass (Costa et al., 2017).

The consortium systems presented similar biomass half-lives (Table 3). This result is supported by the systems resulting in rapid biomass decomposition having similar $\mathrm{C} / \mathrm{N}$ ratios (Figure 3), motivated by the high leaf production in Paiaguas palisadegrass. Ramos et al. (2016) reported that the higher the lignin content and the $\mathrm{C} / \mathrm{N}$ ratio were in the residues, the slower the decomposition.

The decomposition rate of the remaining biomass determines the dwell time of the mulch in the soil, which is influenced by the lignin content and the $\mathrm{C} / \mathrm{N}$ ratio of the residues. According to Noce et al. (2008), grasses generally produce relatively high amounts of biomass that is characterized by a high $\mathrm{C} / \mathrm{N}$ ratio, which increases the persistence of soil cover.

The highest $\mathrm{C} / \mathrm{N}$ ratios among all evaluations were obtained in monocropped sunflower and intercropped sunflower with Paiaguas palisadegrass sown afterwards ( $p>0.05$ ) (Figure 3 ). These results can be attributed to the capacity of sunflower to supplant Paiaguas palisadegrass due to plant structure, with a higher concentration of carbon in the stem than the concentration of nitrogen in the tissues. This characteristic of sunflower favours its use as a rotation crop based on its capacity to produce and leave in the soil high amounts of the residues necessary to increase soil organic matter in tropical regions (Azevedo and Spehar, 2002).

On the other hand, the lowest $\mathrm{C} / \mathrm{N}$ ratio was obtained in monocropped Paiaguas palisadegrass. These results are due to the high leaf production of this grass; the leaves are also less lignified and decompose easily, contributing to the more rapid decomposition of the biomass (Costa et al., 2016).

Normally, the durability of the biomass of forage plants is evaluated by the $\mathrm{C} / \mathrm{N}$ ratio, with a greater decomposition occurring when the ratio is below 25:1 (Costa et al., 2015). Thus, the higher $\mathrm{C} / \mathrm{N}$ ratio observed in sunflower is responsible for the lower biomass loss observed in systems with sunflower.

\section{Agronomic characteristics of soybean and grain yield}

The height of soybean plants was influenced by the different forage systems (Table 1). The greatest heights were observed in the systems with monocropped Paiaguas, 
Table 1. Height of soybean plants, height of first and last pods, pod number, 1000-grain weight $(\mathrm{g})$, and grain yield $\left(\mathrm{kg}^{\mathrm{a}} \mathrm{a}^{-1}\right)$ of soybeans grown under sunflower biomass and monocropped Paiaguas palisadegrass and in mixed systems in different forage systems.

\begin{tabular}{|c|c|c|}
\hline Forage system & Plant height $(\mathrm{cm})$ & Height of first pod (cm) \\
\hline Monocropped sunflowers & $75.41 \mathrm{c}$ & $15.83 \mathrm{~b}$ \\
\hline Monocropped Paiaguas palisadegrass & $87.58 \mathrm{a}$ & $20.25 \mathrm{a}$ \\
\hline Row sunflowers $x$ Paiaguas palisadegrass & $87.16 \mathrm{a}$ & 20.16 a \\
\hline Inter-row sunflowers x Paiaguas palisadegrass & $86.66 \mathrm{a}$ & $18.58 \mathrm{ab}$ \\
\hline Oversown sunflowers $x$ Paiaguas palisadegrass & 80.08 bc & $16.42 \mathrm{~b}$ \\
\hline CV (\%) & 3.73 & 10.10 \\
\hline \multirow[t]{2}{*}{ P-value } & 0.0004 & 0.0132 \\
\hline & Height of last pod (cm) & Pod number \\
\hline Monocropped sunflowers & $76.75 \mathrm{~b}$ & $21.25 \mathrm{~b}$ \\
\hline Monocropped Paiaguas palisadegrass & $89.08 \mathrm{a}$ & $32.25 \mathrm{a}$ \\
\hline Row sunflowers $\mathrm{x}$ Paiaguas palisadegrass & $88.50 \mathrm{a}$ & $31.00 \mathrm{a}$ \\
\hline Inter-row sunflowers x Paiaguas palisadegrass & $86.66 \mathrm{a}$ & $28.75 \mathrm{a}$ \\
\hline Oversown sunflowers x Paiaguas palisadegrass & $78.17 b$ & $21.75 \mathrm{~b}$ \\
\hline CV (\%) & 4.20 & 10.02 \\
\hline \multirow[t]{2}{*}{ P-value } & 0.0005 & 0.0001 \\
\hline & 1000-grain weight (g) & $\begin{array}{c}\text { Grain yield } \\
\left(\mathrm{kg} \mathrm{ha}^{-1}\right)\end{array}$ \\
\hline Monocropped sunflowers & $17.38 \mathrm{bc}$ & $3,942.17 \mathrm{~b}$ \\
\hline Monocropped Paiaguas palisadegrass & $19.84 \mathrm{a}$ & $4,659.70$ a \\
\hline Row sunflowers $\mathrm{x}$ Paiaguas palisadegrass & $18.72 \mathrm{a}$ & $4,405.29$ a \\
\hline Inter-row sunflowers x Paiaguas palisadegrass & $19.05 \mathrm{a}$ & $4,587.12$ a \\
\hline Oversown sunflowers x Paiaguas palisadegrass & $16.63 \mathrm{c}$ & $4,053.48 \mathrm{~b}$ \\
\hline CV (\%) & 5.12 & 4.62 \\
\hline P-value & 0.0024 & 0.0005 \\
\hline
\end{tabular}

Means followed by different letters differ from each other by the Tukey test at the $5 \%$ probability level.

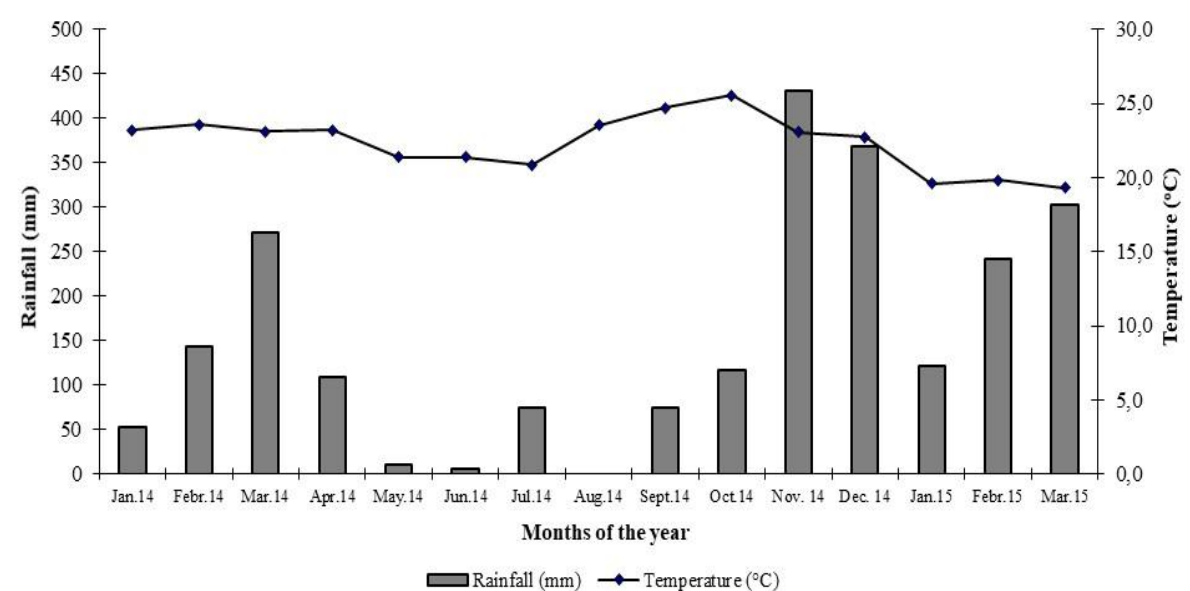

Fig 1. Rainfall and mean temperatures recorded from January 2014 to March 2015 in Rio Verde, Goias, Brazil.

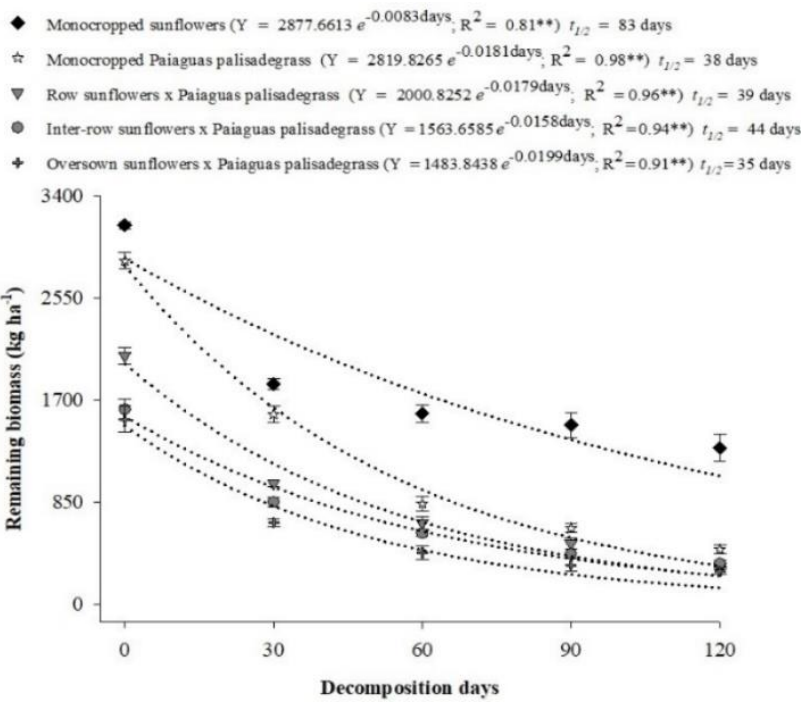

Fig 2. Remaining biomass in different forage systems during soybean cultivation (from 0 to 120 days). 


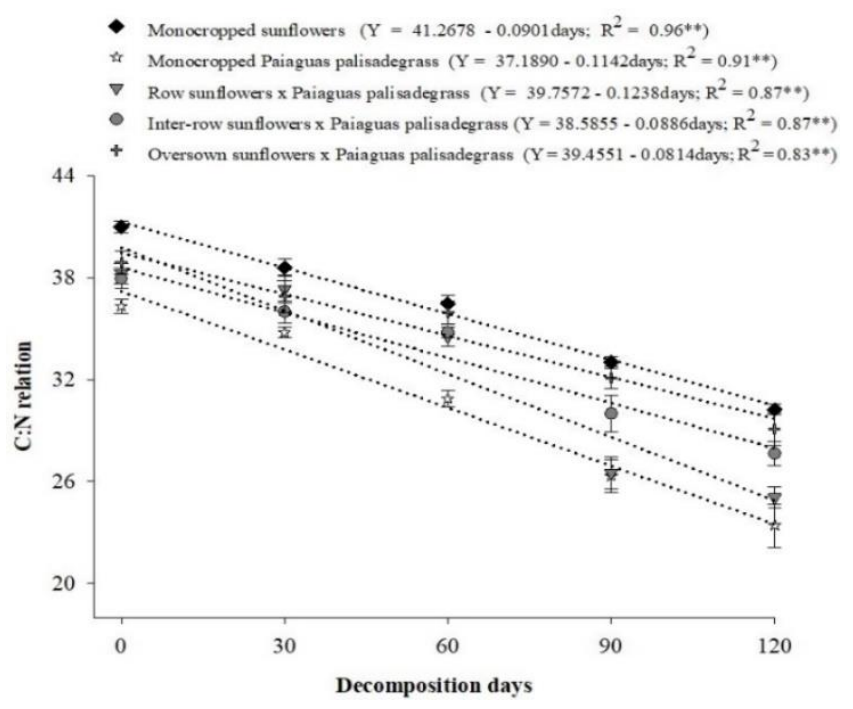

Fig 3. $\mathrm{C} / \mathrm{N}$ ratio in different forage systems during soybean cultivation (from 0 to 120 days).

palisadegrass and Paiaguas palisadegrass intercropped with sunflower in the rows and inter-rows.

According to Costa et al. (2017), Paiaguas palisadegrass presents high water use efficiency. However, even when water availability is low, the presence of Paiaguas palisadegrass can cause competition and interfere with the development of crops grown in a consortium. This species has a $\mathrm{C}_{4}$ photosynthetic metabolism, is highly dependent on luminosity to reach an optimal point in the photosynthetic rate, and has a highly efficient root system for exploring water and soil nutrients; therefore, it is considered a highly competitive species (Taiz and Zaiger, 2010).

The main advantages of Paiaguas palisadegrass are evident when it is cultivated during the dry season. This forage species accumulates more forage than other species due to its capacity for regrowth under conditions of low precipitation (Santos et al., 2016), which favours the production of biomass for the soybean crop.

Table 1 shows that monocropped Paiaguas palisadegrass was the system that presented the highest biomass production and lowest $\mathrm{C} / \mathrm{N}$ ratio (Figure 2 ). In this way, this system provided a greater quantity of nutrients recycled and made available by the low straw half-life ( 28 days). According to Costa et al. (2017), monocropped Paiaguas palisadegrass presented greater cycling and accumulation of nutrients in the remaining biomass. These nutrients available in the system were absorbed by soybean, providing greater growth and consequently higher plant height.

The height of the first pod of the soybean plants was influenced by the residual effect of the biomass of the forage systems (Table 1). The highest values were obtained from the biomass of Paiaguas palisadegrass monocropped and intercropped with sunflower in the rows and inter-rows. These results confirm the results found by Costa et al. (2017), with higher nutrient cycling resulting in greater growth of soybean plants with a higher insertion height of the 1st pod. In the other forage systems, although the first pod heights were statistically similar to those in the previous production, they did not stand out as much as those of the soybean grown in the first two systems.

The height of the last pod followed the same behaviour as the insertion height of the 1st pod (Table 1), with better results for the biomass of Paiaguas palisadegrass monocropped and intercropped with sunflower in the rows and inter-rows.

These results confirm that with greater plant height, a higher incidence of pods will occur. Environmental factors and/or cultural practices affect pod insertion height and plant height. Variations in the heights of the first pod between the lowest 10 and highest $15 \mathrm{~cm}$ have been found (Bastidas et al., 2008).

The 1000 grain weight is a characteristic related to the yield of the soybean crop as well as the number of plants per area, the number of pods per plant, the number of grains per pod, and the grain weight, which are important production components. According to Carvalho et al. (2014), the latter parameter presents the lowest percentage variation due to changes in the growing environment. Generally, the results of soybean development research in no-tillage systems on biomass in pastureland, especially when intercropped, show that biomass residues may be an important factor influencing the grain yield of this legume.

Soybean presented the highest grain yields in the systems with the biomass of Paiaguas palisadegrass monocropped and intercropped with sunflower in the rows and inter-rows (Table 1). The higher biomass production of Paiaguas palisadegrass seems to have resulted in higher nutrient cycling (Costa et al., 2017), higher soybean crop yield, and greater yield of 1000 grains and yield (Table 1).

Although the monocropped sunflower showed a higher proportion of biomass throughout the development of the soybean cycle, soybean yield was lower in this system. This can be explained by the lower soil cover, higher $\mathrm{C} / \mathrm{N}$ ratio (Figure 3), longer straw half-life and lower nutrient cycling compared with those of the systems that include Paiaguas palisadegrass, which is a forage that presents a large number of leaves with excellent soil cover (Costa et al., 2016).

The grain yield per hectare was higher in the systems with monocropped Paiaguas palisadegrass and intercropped Paiaguas palisadegrass with sunflower in the rows and interrows. Thus, the importance of summer crop rotation systems using tropical weeds for increasing soybean grain yield in comparison to the annual monocropped cropping systems is verified. In addition, lower grain yield and grain mass were observed in the monocropped sunflower and sunflower oversown and intercropped with Paiaguas palisadegrass, indicating that the sowing method that 
provides the greatest benefit to soybean is sunflower in the rows and inter-rows intercropped with Paiaguas palisadegrass, which decreases competition among the plants.

\section{Materials and Methods}

\section{Site description}

The experiment was conducted in the field $\left(17^{\circ} 48^{\prime} \mathrm{S} ; 50^{\circ} 55^{\prime}\right.$ $\mathrm{W}$; and $748 \mathrm{~m}$ altitude) at the Federal Institute of Goiás (Instituto Federal Goiano) in the municipality of Rio Verde, Goiás, in the 2014 off season on a dystroferric Red Latosol soil.

Soil samples were collected from the $0-20 \mathrm{~cm}$ layer to assess the physical and chemical characteristics of the experimental area prior to planting the forage systems. The following values were obtained: clay, $520 \mathrm{~g} \mathrm{~kg}^{-1}$; silt, $150 \mathrm{~g} \mathrm{~kg}^{-1}$; sand, $330 \mathrm{~g} \mathrm{~kg}^{-1} ; \mathrm{pH}$ in $\mathrm{CaCl}_{2}, 5.02 ; \mathrm{Ca}, 4.62 ; \mathrm{Mg}, 1.24 ; \mathrm{Al}, 0.01$; $\mathrm{Al}+\mathrm{H}, 6.00 ; \mathrm{K}_{2} \mathrm{O}, 0.63$; cation exchange capacity (CEC), 12.52 in $\mathrm{cmol}_{\mathrm{c}} \mathrm{dm}^{-3} ; \mathrm{P}, 8.43 \mathrm{~g} \mathrm{dm}^{-3} ; \mathrm{Cu}, 3.5 \mathrm{~g} \mathrm{dm}^{-3} ; \mathrm{Zn}, 4.1 \mathrm{~g} \mathrm{dm}^{-3}$; Fe, $34.0 \mathrm{~g} \mathrm{dm}^{-3}$; and organic matter (O.M.), $36.76 \mathrm{~g} \mathrm{dm}^{-3}$.

Tillage was performed by weed desiccation using the herbicide glyphosate at a dose of $1.680 \mathrm{~g}$ active ingredient (a.i.) $\mathrm{ha}^{-1}$ in a volume of $150 \mathrm{~L}$ broth $\mathrm{ha}^{-1}$. Disking was performed at $40 \mathrm{~cm}$ depth 20 days after desiccation using a disk harrow to remove the seed bank of colonião grass and weeds in the area.

A week before planting, $1.0 \mathrm{t} \mathrm{ha}^{-1}$ limestone filler was applied and a second disking operation was performed at 20 $\mathrm{cm}$ depth followed by levelling. Subsequently, sowing furrows were opened using a planter, and the sowing furrows of Paiaguas palisadegrass in sunflower inter-rows and oversown plots were manually opened using hoes.

\section{Experimental design and treatments}

The experimental design consisted of randomized blocks with four replicates and used the following forage systems: monocropped sunflower; monocropped Paiaguas palisadegrass; sunflower row-intercropped with Paiaguas palisadegrass; sunflower inter-row-intercropped with Paiaguas palisadegrass; and sunflower oversown and intercropped with Paiaguas palisadegrass. There were 20 experimental plots, and Charrua (triple, semi-early, blackachene hybrid with a high oil content) was the sunflower cultivar.

\section{Implantation of crops and cultural practices}

Sowing was performed on February 17,2014 , using $80 \mathrm{~kg}$ ha ${ }^{1} \mathrm{P}_{2} \mathrm{O}_{5}, 20 \mathrm{~kg} \mathrm{ha}^{-1}$ FTE BR 12 and $1.5 \mathrm{~kg}$ boron, and triple super phosphate, frits (fritted trace elements) and boric acid as sources, respectively. The sunflowers were sown to a depth of $3 \mathrm{~cm}$ in the rows and inter-rows and were oversown intercropped and monocropped. Paiaguas palisadegrass was sown to a depth of $6 \mathrm{~cm}$ in the row intercropping and at a distance of $40 \mathrm{~cm}$ from the sunflower row in the inter-row intercropping. In the oversown intercropping, Paiaguas palisadegrass was sown 15 days after the emergence of sunflowers in the inter-rows at 40 $\mathrm{cm}$. Sunflower seeds at $6 \mathrm{~kg} \mathrm{~m}^{-1}$ and pure and viable Paiaguas palisadegrass seeds at $5 \mathrm{~kg} \mathrm{ha}^{-1}$ were used. The plots consisted of eight $3.0 \mathrm{~m}$ long rows in all forage systems.
Manual weeding was performed weekly up to 50 days after emergence (DAE) for weed control. Pest control was manually performed on March 03, 2014, by applying the insecticides Losban (contact) and Nomolt (physiological) at doses of 120 and $7.5 \mathrm{~g}$ a.i. ha ${ }^{-1}$ to control the sunflower patch butterfly (Chlosyne lacinia saundersii) and southern armyworm (Spodoptera eridania), respectively, and the fungicide Prior Extra on 04/07/2014 at a dose of $60+24 \mathrm{~g}$ a.i. $\mathrm{ha}^{-1}$ to control sunflower leaf blight (Alternaria helianthi) and powdery mildew (Erysiphe cichoracearum). During the experiment, the daily rainfall and mean monthly temperature were monitored (Figure 1).

\section{Harvesting of crops}

Harvesting was performed manually at 130 DAE when the plants were at physiological maturity. After the sunflower harvest, the dry mass production of the Paiaguas palisadegrass was evaluated until the beginning of the rainy season (September). After both evaluation cuts, the uniformity cut of all the plants of the experimental area was carried out at the same height as for the evaluated plants, and the residue resulting from the standardization was removed from the area. Afterwards, Paiaguas palisadegrass remained for regrowth, with the intention of desiccating it for the formation of biomass for the planting of soybean in the next harvest.

\section{Desiccation and sowing of soybean}

Desiccation was performed on 10/31/14 with the application of $4.5 \mathrm{~L} \mathrm{ha}^{-1}$ of Transorb. One day before soybean planting, the soil cover efficiency by the biomass of the forage systems was visually evaluated, which consisted of the assignment of grades from zero (uncovered soil) to 100 (soil totally covered). Then, the production of biomass was evaluated by using a $1 \times 1 \mathrm{~m}$ square and cutting the material close to the soil. After weighing $500 \mathrm{~g}$, the material was separated and brought to the oven at $65^{\circ} \mathrm{C}$ for determination of the dry biomass. On November 20, 2014, the sowing of the Intacta RR soybean was carried out with the use of a seeder-fertilizer.

\section{Evaluation of remaining biomass and $C / N$ ratio}

To quantify biomass production, straw samples were collected by randomly placing a $1 \mathrm{~m}^{2}$ square within each plot. The plant material was cut using a height of $0.05 \mathrm{~m}$ from the soil surface as a reference. The cut material was weighed, the samples were dried to constant weight in a forced-air oven at $55^{\circ} \mathrm{C}$, and the amounts were extrapolated to $\mathrm{kg} \mathrm{ha}^{-1}$.

After this management procedure (cutting), the fresh biomass from each plot was placed in nylon litter bags for decomposition (Thomas and Asakawa, 1993). The bags consisted of a 2-mm mesh and measured $15 \times 20 \mathrm{~cm}$. Four bags containing residues of the studied species in an amount proportional to the dry biomass produced per hectare were deposited in direct contact with the soil. At 30, 60, 90 and 120 days after cutting, one litter bag was removed from each plot to evaluate the remaining biomass and determine the decomposition time during the 120 -day period (soybean harvest).

After cleaning the material in the laboratory to remove adhered soil, it was dried in an oven at $55^{\circ} \mathrm{C}$ for 72 hours to 
obtain the dry biomass. Next, samples of the plant material were ground to determine the concentrations of nitrogen and carbon according to the method proposed by Malavolta et al. (1997).

\section{Statistical analysis}

The data were submitted to analysis of variance using the program R version 3.1.1 (2014) and using the ExpDes package (Ferreira et al., 2014). The averages were compared by the Tukey test, with a significance level of $5 \%$ of probability.

To describe the decomposition of plant residues, the data were adjusted in an exponential mathematical model using the Sigma Plot application, and for the comparisons of regression equations after linearization, the procedure described in Snedecor and Cochran (1989) was used. To calculate the half-life ( $\mathrm{t} 1 / 2$ ), that is, the time required for $50 \%$ of the remaining biomass to be decomposed, the equation of Paul and Clark (1989) was used: t1 / $2=0.693$ / $k$, where $t 1 / 2$ is the half-life of the dry biomass, and $k$ is the decomposition constant of the dry biomass.

\section{Conclusion}

The monocropped sunflower and Paiaguas palisadegrass presented higher biomass production throughout the soybean development cycle, with slower decomposition, representing a strategy to increase soil cover efficiency, mainly in the period prior to summer planting.

The soybean cultivated in the biomass of the monocropped Paiaguas palisadegrass and the Paiaguas palisadegrass intercropped in the rows and inter-rows presented better yields and was positively influenced by the production parameters. Therefore, sunflower intercropped with Paiaguas palisadegrass in these forms of sowing during the off season in the Central-West Region of Brazil was shown to be a promising and sustainable cultivation technique for the production of biomass for no-tillage systems.

\section{Acknowledgments}

The Foundation for Research Support of the State of Goiás (FAPEG) for the project's funding and the Goiano Federal Institute for research support.

\section{References}

Almeida REM, Favarin JLI, Otto R, Pierozan Junior C, Oliveira SM, Tezotto T, Lago BC (2017) Effects of nitrogen fertilization on yield components in a corn-palisadegrass intercropping system. Aust J Crop Sci. 11(3):352-360.

Azevedo DMP, Spehar CR (2002) Decomposição da palhada de culturas para plantio no período de safrinha em solos de tabuleiros costeiros. Embrapa Meio Norte, Comunicado Técnico 147.

Bastidas AM, Setryono TD, Dobermann A (2008) Data de semeadura da soja: Os impactos vegetativo, reprodutivo e agronômico. Crop Sci. 48(2):727-740.

Carvalho PCF, Moraes A, Pontes LS, Anghinoni I, Sulc RM, Botello C (2014) Definições e terminologias para sistema integrado de produção agropecuária. Cienc Agron. 45(5):1040-1046.
Costa NR, Andreotti M, Ulian NA, Costa BS, Pariz CM, Teixeira Filho MCM (2015) Acúmulo de nutrientes e tempo de decomposição da palhada de espécies forrageiras em função de épocas de semeadura. Biosc J. 31(3):818-829.

Costa RRGF, Costa KAP, Assis RL, Santos CB, Severiano EC, Rocha AFS, Aquino MM (2016) Dynamics of biomass of pearl millet and Paiaguas palisadegrass in different forage systems and sowing periods in yield of soybean. Afr J Agric Res. 11(45):4661-4673.

Costa RRGF, Costa KAP, Severiano EC, Santos CB, Rocha AFS, Souza WF, Brandstetter EV, Castro WA (2017) Nutrients cycling and accumulation in pearl millet and Paiaguas palisadegrass biomass in different forage systems and sowing periods. Sci Agric. 18(4):166-178.

Cruvinel WS, Costa KAP, Da Silva AG, Severiano EC, Ribeiro MG (2017) Intercropping of sunflower with Brachiaria brizantha cultivars during two sowing seasons in the interim harvest. Semin Cienc Agrar. 38(5):173-3191.

Ferreira EB, Cavalcanti PP, Nogueira, DA (2014) ExpDes: An R Package for ANOVA and Experimental Designs. Applied Mathematics. 5:2952-2958.

Guarnieri A, Costa KAP, Severiano EC, Silva AG, Oliveira SS, Santos CB (2019) Agronomic and productive characteristics of maize and Paiaguas palisadegrass in integrated production systems. Semin Cienc Agrar. 40(3):1185-1198.

Horvathy Neto A, Silva AG, Teixeira IR, Simon GA, Assis RL, Rocha VS (2012) Consórcio sorgo e braquiária para produção de grãos e biomassa na entressafra. Rev. Bras. Cienc Agrár. 7(supl.):743-749.

Lobo TF, Grassi Filho H, Coelho HA (2012) Efeito da adubação nitrogenada na produtividade do girassol. Rev Cient. 40(1):59-68.

Machado LAZ, Cecato U, Comunello E, Concenço G, Ceccon G (2017) Estabelecimento de forrageiras perenes em consórcio com soja, para sistemas integrados de produção agropecuária. Pesq Agropec Bras. 52(7):521-529.

Malavolta E, Vitti GC, Oliveira AS (2ed) (1997) Avaliação do estado nutricional de plantas: princípios e aplicações. Piracicaba Potafos.

Miguel ASDCS, Pacheco LP, Carvalho, Íc, Souza ED, Feitosa PB, Petter FA (2018) Phytomass and nutrient release in soybean cultivation systems under no-tillage. Pesq Agropec Bras. 53(10):1119-1131.

Noce MA, Souza IF, Karam D, França AC, Maciel GM (2008) Influência da palhada de gramíneas forrageiras sobre o desenvolvimento da planta de milho e das plantas daninhas. Rev Bras de Milho e Sorgo. 7(3):265-278.

Oliveira, SM, Almeida, REM, Pierozan Junior, Clovis, Reis, AFB, Souza, LFN, Favarin, JL (2019) Contribution of corn intercropped with Brachiaria species to nutrient cycling. Pesq Agropec Trop. 49:1-9.

Paul EA, Clark FE. Soil microbiology and biochemistry (1989). San Diego, Academic Press.

Ramos NP, Yamaguchi CS, Pires AMM, Rossetto R, Possenti RA, Packer AP, Cabral OMR, Andrade, C A (2016) Decomposição de palha de cana-de-açúcar recolhida em diferentes níveis após a colheita mecânica. Pesq Agropec Bras. 51(9):492-1500.

Santos CB, Costa KAP, Oliveira IP, Severiano EC, Costa RRGF, Silva AG, Silva JT (2016) Production and nutritional characteristics of sunflowers and Paiaguas palisadegrass under different forage systems in the off season. Biosc J. 32(2):460 - 470. 
Silva HP, Gama JCM, Neves JMG, Brandão Junior DS, Karam D (2010) Levantamento das plantas espontâneas na cultura do girassol. Rev Verde. 5(1):162-167.

Snedecor GW, Cochran WG (1989). Statistical methods, 8thEdn. Ames: lowa State Univ. Press

lowa.

Souza FR, Silva IM, Pellin DMP, Bergamin AC, Silva RP (2015) Características agronômicas do cultivo de girassol consorciado com Brachiaria ruziziensis. Rev Cienc Agronôn. 46(1):110-116.
Taiz L, Zeiger E. Plant physiology. (5 ed.) (2010) Sunderland, Sinauer Associates, 700p.

Thomas RJ, Asakawa NM (1993) Decomposition of leaf litter from tropical forage grasses and legumes. $\mathrm{S}$ Biol and Biochem. 25(10):1351-1361. 